\title{
Thermocrinis minervae sp. nov., a hydrogen- and sulfur-oxidizing, thermophilic member of the Aquificales from a Costa Rican terrestrial hot spring
}

Correspondence Anna-Louise Reysenbach reysenbacha@pdx.edu

\author{
Sara L. Caldwell, ${ }^{1}$ Yitai Liu, ${ }^{1}$ Isabel Ferrera, ${ }^{2}$ Terry Beveridge ${ }^{3}$ \\ and Anna-Louise Reysenbach ${ }^{1}$
}

\author{
${ }^{1}$ Department of Biology, Portland State University, PO Box 751, Portland, OR 97207-0751, USA \\ ${ }^{2}$ Departament de Biologia Marina i Oceanografia, Institut de Ciències del Mar-CMIMA, CSIC, \\ Passeig Marítim de la Barceloneta 37-49, E-08003 Barcelona, Catalunya, Spain \\ ${ }^{3}$ Department of Microbiology, College of Biological Science, University of Guelph, Guelph, ON N1G \\ 2W1, Canada
}

\begin{abstract}
A thermophilic bacterium, designated strain $\mathrm{CR} 11^{\top}$, was isolated from a filamentous sample collected from a terrestrial hot spring on the south-western foothills of the Rincón volcano in Costa Rica. The Gram-negative cells are approximately 2.4-3.9 $\mu \mathrm{m}$ long and 0.5-0.6 $\mu \mathrm{m}$ wide and are motile rods with polar flagella. Strain $\mathrm{CR} 11^{\top}$ grows between 65 and $85{ }^{\circ} \mathrm{C}$ (optimum $75{ }^{\circ} \mathrm{C}$, doubling time $4.5 \mathrm{~h}$ ) and between $\mathrm{pH} 4.8$ and 7.8 (optimum $\mathrm{pH}$ 5.9-6.5). The isolate grows chemolithotrophically with $\mathrm{S}^{0}, \mathrm{~S}_{2} \mathrm{O}_{3}^{2-}$ or $\mathrm{H}_{2}$ as the electron donor and with $\mathrm{O}_{2}$ (up to $16 \%$, $\mathrm{v} / \mathrm{v}$ ) as the sole electron acceptor. The isolate can grow on mannose, glucose, maltose, succinate, peptone, Casamino acids, starch, citrate and yeast extract in the presence of oxygen (4\%) and $\mathrm{S}^{0}$. Growth occurs only at $\mathrm{NaCl}$ concentrations below $0.4 \%(\mathrm{w} / \mathrm{v})$. The $\mathrm{G}+\mathrm{C}$ content of strain $\mathrm{CR} 11^{\top}$ is $40.3 \mathrm{~mol} \%$. Phylogenetic analysis of the $16 \mathrm{~S}$ rRNA gene sequence places the strain as a close relative of Thermocrinis ruber OC $1 / 4^{\top}$ (95.7\% sequence similarity). Based on phylogenetic and physiological characteristics, we propose the name Thermocrinis minervae sp. nov., with $\mathrm{CR} 11^{\top}$ (=DSM $19557^{\top}=$ ATCC BAA $\left.-1533^{\top}\right)$ as the type strain.
\end{abstract}

The members of the order Aquificales, represented by the families Aquificaceae, Hydrogenothermaceae and Desulfurobacteriaceae, are thermophilic bacteria that are widely distributed in hydrothermal systems and include microaerophilic chemolithotrophs and heterotrophs. Phylogenetic analysis of $16 \mathrm{~S}$ rRNA gene sequences places the Aquificales as one of the deeply branching lineages within the Bacteria (Burggraf et al., 1992; Pitulle et al., 1994; Di Giulio, 2003a, b, c; Barion et al., 2007).

The family Aquificaceae includes the genera Aquifex, Thermocrinis, Hydrogenobacter, Hydrogenivirga and Hydrogenobaculum. Aquifex pyrophilus, originally isolated from a submarine hydrothermal vent system in Iceland (Huber et al., 1992), was the first described representative of this family, although numerous described Hydrogenobacter strains (Kryukov et al., 1983; Kawasumi et al., 1984; Kristjansson et al., 1985; Nishihara et al., 1990)

The GenBank/EMBL/DDBJ accession number for the partial 16S rRNA gene sequence of strain $\mathrm{CR} 11^{\top}$ is $\mathrm{AM} 260555$.

Graphs showing the effect of temperature and $\mathrm{pH}$ on growth of strain $\mathrm{CR} 11^{\top}$ are available as supplementary material with the online version of this paper. also grouped within the Aquificaceae once their 16S rRNA gene sequences were determined (Burggraf et al., 1992; Pitulle et al., 1994). Another clade within the Aquificaceae was reported from a culture-independent, molecular phylogenetic assessment of the diversity associated with the pink filamentous streamers from Octopus Spring in Yellowstone National Park (Reysenbach et al., 1994). Following this study, Huber et al. (1998) isolated the dominant member of the Aquificales from this hot spring on a medium containing organic acids and named it Thermocrinis ruber. Subsequently, numerous new Thermocrinis isolates, including a strain assigned to the novel species Thermocrinis albus, were obtained from hot springs in Russia, Iceland and Yellowstone National Park (Eder \& Huber, 2002).

Cultivation studies and associated geochemical analyses (Huber et al., 1998; Eder \& Huber, 2002; Blank et al., 2002; Hall et al., 2008; Connon et al., 2008) suggest that the metabolic activities of this group may contribute significantly to biogeochemical cycling in certain hydrothermal systems. Like the other members of the Aquificales, T. ruber and T. albus are dominant primary producers (Blank et al., 2002; Eder \& Huber, 2002) in many ecosystems where 
photosynthesis is limited by high temperatures. Their ability to oxidize sulfur in laboratory cultures (Huber et al., 1998; Eder \& Huber, 2002) suggests that these bacteria may also contribute to sulfur cycling in these environments. Additionally, 16S rRNA gene sequence studies of a biofilm associated with As(III) oxidation in the Alvord hot spring in Oregon indicated the presence of bacteria related to Thermocrinis and other genera of the Aquificales (Connon et al., 2008).

T. ruber and T. albus share similar physiological properties, including $\mathrm{pH}$, temperature and salinity optima (Huber et al., 1998; Eder \& Huber, 2002). Isolates of both species are able to oxidize hydrogen, sulfur and thiosulfate with oxygen as the sole electron acceptor and have similar distributions of fatty acids and glycerol monoethers (Jahnke et al., 2001). However, T. ruber can also grow heterotrophically with formate and formamide, while $T$. albus appears to be a strict chemolithoautotroph (Huber et al., 1998; Eder \& Huber, 2002). Based on 16S rRNA gene sequences, these isolates are somewhat distantly related (5.1\% sequence difference; Eder \& Huber, 2002).

Here, we report the isolation and characterization of a strain that represents a novel species of Thermocrinis. This strain is the first member of the Aquificales isolated from Costa Rica and is capable of using a relatively large number of organic carbon sources, further expanding the geographical range and metabolic diversity of this group.

\section{Sample collection, enrichment and isolation}

Filamentous biomass samples were collected aseptically from a thermal spring $\left(93{ }^{\circ} \mathrm{C}, \mathrm{pH} 7.0\right)$ on the southwestern foothills of the Rincón de la Vieja volcano in Costa Rica. A subsample was inoculated into $5 \mathrm{ml}$ modified $\mathrm{MSH}$ medium ( $\mathrm{pH}$ 6.2) under a gas phase of $\mathrm{CO}_{2} / \mathrm{H}_{2}(20: 80)$ (Aguiar et al., 2004). Prior to inoculation, $\mathrm{O}_{2}(4 \%)$ was added to the medium. Enrichments were incubated at $80{ }^{\circ} \mathrm{C}$, without agitation, until the tubes became turbid and contained motile rods under phase-contrast microscopy. Samples of these cultures were transferred immediately into the same medium and purified by multiple dilutionto-extinction serial transfers. Purity of the isolate was determined by $16 \mathrm{~S}$ rRNA gene sequencing. The resulting pure culture was designated strain $\mathrm{CR} 11^{\mathrm{T}}$ and was characterized further. The isolate grew better with $S^{0}$ than with $\mathrm{H}_{2}$ as the electron donor. Therefore, unless otherwise noted, all subsequent growth experiments used a modified MSH medium (Aguiar et al., 2004) supplemented with approximately $0.06 \%(\mathrm{w} / \mathrm{v}) \mathrm{S}^{0}$ and $4 \%(\mathrm{v} / \mathrm{v}) \mathrm{O}_{2}$.

\section{Morphology}

Cells were routinely monitored under phase-contrast microscopy using an Olympus BX60 microscope. Electron microscope examination was performed as described previously (Nakagawa et al., 2005). Thin sections were prepared by treating fixed cells with $2 \%(\mathrm{w} / \mathrm{v})$ osmium tetroxide and en-block staining with $2 \%$ uranyl acetate as described by Beveridge et al. (1994). Cells were then dehydrated in ethanol and embedded in LR White. Sectioned cells were mounted on carbon- and Formvarcoated 200-mesh grids and stained with uranyl acetate and lead citrate. To create negative stains, grids were coated with a thin cell suspension, dried and stained with $2 \%$ uranyl acetate.

Cells of strain $\mathrm{CR} 11^{\mathrm{T}}$ are motile, Gram-negative rods that vary in length from approximately 2.4 to $3.9 \mu \mathrm{m}$ and from 0.5 to $0.6 \mu \mathrm{m}$ in width (Fig. 1c). Cells did not form filaments during growth, although we did not try to stimulate filament formation as reported by Huber et al. (1998). The Gram-negative envelope has only an outer membrane as the surface component (Fig. 1a). Approximately $5 \%$ of the cells observed by transmission electron microscopy also have cytoplasmic structures of unknown function (Fig. 1b). These structures have been reported previously in other members of the Aquificales (Götz et al., 2002; Aguiar et al., 2004; Flores et al., 2008). Transmission electron micrographs of negatively stained cells show amphitrichous flagella (Fig. 1c).

\section{Growth characteristics}

Growth of the isolate was determined by direct cell counts using a Petroff-Hauser counting chamber and a phasecontrast microscope (Olympus BX60). All experiments were performed in triplicate at optimum temperature and $\mathrm{pH}$ unless otherwise noted.

The isolate grew between 65 and $85{ }^{\circ} \mathrm{C}$, with optimum growth occurring at about $75{ }^{\circ} \mathrm{C}$ (doubling time $4.5 \mathrm{~h}$; Supplementary Fig. S1a, available in IJSEM Online). This growth range is below the temperature measured in the spring during sample collection. It is well-established that growth under laboratory conditions may not directly reflect the growth conditions in the environment; alternatively, a lower-temperature variant was selected for in this study. The effect of $\mathrm{pH}$ on growth was determined by adjusting the medium using $10 \mathrm{mM}$ acetate/acetic acid buffer ( $\mathrm{pH} 4-5$ ), MES ( $\mathrm{pH}$ 5-6.5), HEPES ( $\mathrm{pH}$ 7), PIPES $(\mathrm{pH} 7-7.5)$ and Tris $(\mathrm{pH} 7.5-8.0)$. Strain $\mathrm{CR} 11^{\mathrm{T}}$ grew between $\mathrm{pH} 4.8$ and 7.8 and optimally between $\mathrm{pH} 5.9$ and 6.5 (Supplementary Fig. S1b). No growth occurred below $\mathrm{pH} 4.8$ or above $\mathrm{pH} 7.8$. NaCl requirements for growth of the isolate were determined from 0 to $1 \% \mathrm{NaCl}(\mathrm{w} / \mathrm{v})$ in modified MSH medium. The isolate grew in medium containing $0-0.4 \% \mathrm{NaCl}$.

Electron donors and acceptors were added to modified MSH medium without $\mathrm{S}_{2} \mathrm{O}_{3}^{2-}$ (since it may be used as an electron donor) and containing a reduced concentration of $\mathrm{MgSO}_{4} \cdot 7 \mathrm{H}_{2} \mathrm{O}\left(4 \mathrm{~g} \mathrm{l}^{-1}\right)$. Electron couples were added aseptically after autoclaving and at concentrations reported by Aguiar et al. (2004). Medium used for determining growth of $\mathrm{CR} 11^{\mathrm{T}}$ with $\mathrm{H}_{2}$ as the electron donor was prepared with $\mathrm{H}_{2} / \mathrm{CO}_{2}(80: 20)$ as the gas phase and with $\mathrm{S}^{0}$, 

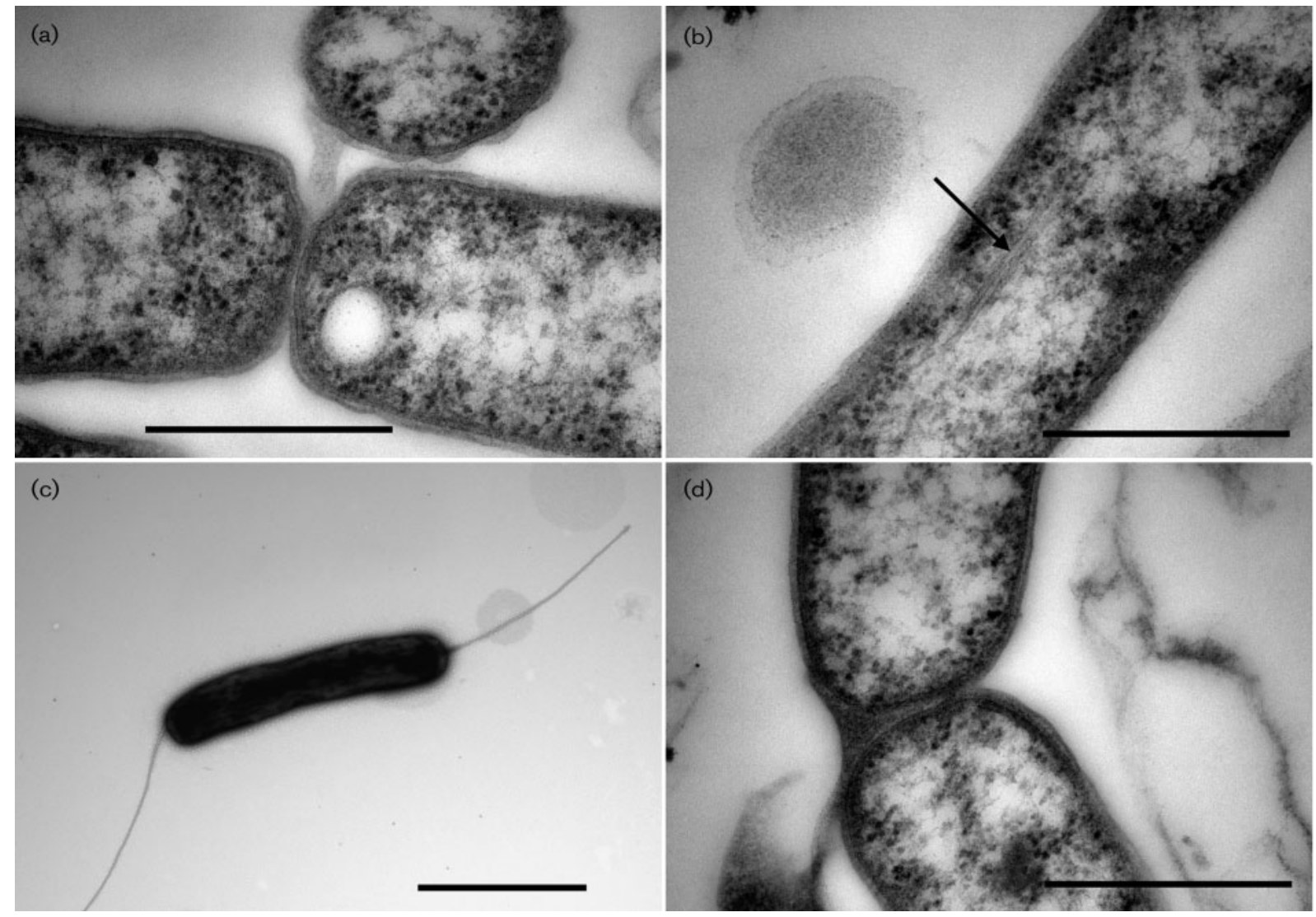

Fig. 1. Transmission electron micrographs of thin sections $(a, b, d)$ and a negatively stained cell (c) of strain $C R 11^{\top}$. The arrow in (b) indicates an example of the cytoplasmic structures with unknown function. Bars, $0.5 \mu \mathrm{m}(\mathrm{a}, \mathrm{b}, \mathrm{d})$ and $2 \mu \mathrm{m}$ (c).

$\mathrm{S}_{2} \mathrm{O}_{3}^{2-}, \mathrm{NO}_{3}^{-}, \mathrm{SO}_{3}^{2-}, \mathrm{SO}_{4}^{2-}$, arsenate $\left(\right.$ as $\left.\mathrm{Na}_{2} \mathrm{HAsO}_{4} .7 \mathrm{H}_{2} \mathrm{O}\right)$, arsenite (as $\mathrm{NaAsO}_{2}$ ), selenate $\left(\right.$ as $\mathrm{Na}_{2} \mathrm{SeO}_{4}$ ) or selenite (as $\mathrm{Na}_{2} \mathrm{SeO}_{3}$ ) as the electron acceptor. Growth with all other electron couples was determined using medium with a gas phase of $\mathrm{N}_{2} / \mathrm{CO}_{2}(80: 20)$. Electron donors and acceptors were added to this medium as follows: $\mathrm{S}_{2} \mathrm{O}_{3}^{2-} / \mathrm{Fe}^{3+}$ (as ferric citrate), $\mathrm{Fe}^{2+}$ (as $\mathrm{FeCl}_{2}$ )/ $\mathrm{O}_{2}, \mathrm{Fe}^{2+}$ (as $\mathrm{FeCl}_{2}$ ) $/ \mathrm{NO}_{3}^{-}, \mathrm{S}_{2} \mathrm{O}_{3}^{2-}$ / $\mathrm{NO}_{3}^{-}, \mathrm{NH}_{4}^{+} / \mathrm{O}_{2}, \mathrm{NH}_{4}^{+} / \mathrm{NO}_{2}^{-}, \mathrm{S}_{2} \mathrm{O}_{3}^{2-} / \mathrm{SO}_{4}^{2-}, \mathrm{SO}_{3}^{2-} / \mathrm{O}_{2}$, $\mathrm{S}_{2} \mathrm{O}_{3}^{2-}$ /arsenate (as $\mathrm{Na}_{2} \mathrm{HAsO}_{4} \cdot 7 \mathrm{H}_{2} \mathrm{O}$ ), arsenite (as $\left.\mathrm{NaAsO}_{2}\right) / \mathrm{O}_{2}, \mathrm{~S}_{2} \mathrm{O}_{3}^{2-}$ /selenate (as $\mathrm{Na}_{2} \mathrm{SeO}_{4}$ ), $\mathrm{S}^{0}$ /selenite (as $\mathrm{Na}_{2} \mathrm{SeO}_{3}$ ) and $\mathrm{S}_{2} \mathrm{O}_{3}^{2-}$ /selenite. Strain $\mathrm{CR} 11^{\mathrm{T}}$ grew with $\mathrm{H}_{2}, \mathrm{~S}^{0}$ and $\mathrm{S}_{2} \mathrm{O}_{3}^{2-}$ as electron donors and with $\mathrm{O}_{2}$ as the sole electron acceptor. The isolate grew at $\mathrm{O}_{2}$ concentrations between 2 and $16 \%(\mathrm{v} / \mathrm{v})$. However, growth of the isolate was weak below $4 \%$ and above $13 \%(\mathrm{v} / \mathrm{v})$ oxygen.

Heterotrophic growth of CR $11^{\mathrm{T}}$ was determined by adding carbon sources at concentrations reported by Aguiar et al. (2004) to modified MSH medium containing no $\mathrm{CO}_{2}$ or $\mathrm{S}_{2} \mathrm{O}_{3}^{2-}$. Growth was monitored in the presence of $\mathrm{O}_{2}$ as an electron acceptor and $S^{0}$ as an electron donor. Cultures were also incubated in the absence of $\mathrm{O}_{2}$ and $\mathrm{S}^{0}$ to test for fermentative growth. Cultures were transferred $(5 \%)$ at least twice in the same substrate combinations to ensure that the cultures were not growing on the carried-over medium. Strain CR $11^{\mathrm{T}}$ grew with $0.1 \%$ mannose, glucose, maltose, succinate, Bacto peptone, Casamino acids, starch, citrate and yeast extract as carbon sources with $S^{0}$ as the electron donor and $\mathrm{O}_{2}(4 \% \mathrm{v} / \mathrm{v})$ as the electron acceptor. No growth was detected under anaerobic conditions or in the absence of $S^{0}$. Growth did not occur with sucrose, fructose, lactate, malate, oxalate, acetate, formaldehyde, propionate, sorbitol, methanol, tartaric acid, formamide, formate or 2-propanol as the sole carbon source.

\section{DNA composition and phylogenetic analysis}

DNA base composition (mol\% G $+\mathrm{C}$ ) was determined by thermal denaturation of genomic DNA (Marmur \& Doty, 1962). DNA was extracted from a pure culture of CR $11^{\mathrm{T}}$ (1 l) using the Qiagen Genomic-tip 100/G DNA extraction kit following the manufacturer's protocol. The $\mathrm{G}+\mathrm{C}$ content of $\mathrm{CR} 11^{\mathrm{T}}$ is $40.3 \mathrm{~mol} \%$. This value is lower than the values reported for other Thermocrinis isolates (Table 1), but it is within the range of $\mathrm{G}+\mathrm{C}$ content reported for other members of the Aquificaceae (the lowest reported value is $35 \mathrm{~mol} \%$, for Hydrogenobaculum acidophilum; Shima \& Suzuki, 1993). 
Table 1. Comparison of physiological properties and DNA base composition between $\mathrm{CR} 11^{\top}$ and other described representatives of Thermocrinis

All three strains use only $\mathrm{H}_{2}, \mathrm{~S}^{0}$ and $\mathrm{S}_{2} \mathrm{O}_{3}^{2-}$ as electron donors and $\mathrm{O}_{2}$ as electron acceptor. Optimum NaCl concentrations for growth have not been reported for any of the strains. NR, Not reported.

\begin{tabular}{|c|c|c|c|}
\hline Property & Strain CR11 ${ }^{\mathrm{T}}$ & T. ruber OC $1 / 4^{\mathrm{T}}$ & T. albus HI $11 / 12^{\mathrm{T}}$ \\
\hline Origin & Terrestrial hot spring, Costa Rica & $\begin{array}{c}\text { Octopus Spring, Yellowstone } \\
\text { National Park }\end{array}$ & Terrestrial hot spring, Iceland \\
\hline Temperature range (optimum) $\left({ }^{\circ} \mathrm{C}\right)$ & $65-85(75)$ & $44-89(80)$ & $55-89$ (NR) \\
\hline $\mathrm{pH}$ range (optimum) & $4.8-7.8(5.9-6.5)$ & NR $(7-8.5)$ & NR $(7)$ \\
\hline Organic carbon sources & $\begin{array}{l}\text { Yeast, mannose, glucose, maltose, } \\
\text { succinate, peptone, Casamino } \\
\text { acids, starch, citrate }\end{array}$ & Formate, formamide & None \\
\hline DNA G $+\mathrm{C}$ content $(\mathrm{mol} \%)$ & 40.3 & 47.2 & 49.6 \\
\hline
\end{tabular}

The 16S rRNA gene was amplified by PCR and sequenced as described by Ferrera et al. (2007). The nearly full-length sequence of the 16S rRNA gene was assembled using AutoAssembler (Applied Biosystems) and compared using a BLAST search against the NCBI non-redundant database. $16 \mathrm{~S}$ rRNA gene sequences were aligned manually using the ARB program (Ludwig et al., 2004; http://www.arb-home.de) based on the constraints of the secondary structure of the 16S rRNA molecule. The similarities in 16S rRNA gene sequences of $C R 11^{\mathrm{T}}$ and the more closely related members of the Aquificaceae were calculated in ARB using 1469 homologous nucleotides within the ThermocrinisHydrogenobacter group. Phylogenetic trees were constructed in PAUP $^{*}$ (Swofford, 2003) using representative sequences of all members of the Aquificales and including only unambiguously aligned nucleotides (1370 nt). Neighbour-joining (NJ; 1000 bootstrap replications) and maximum-likelihood (ML; 100 bootstrap replications) analyses were performed in ARB and PAUP ${ }^{\star}$ as described previously (Ferrera et al., 2007). Since the NJ and ML tree topologies are nearly identical, only the ML tree is shown in Fig. 2.

\section{Comparison with related species}

The 16S rRNA gene sequence analysis places strain CR $11^{\mathrm{T}}$ within a novel species of the genus Thermocrinis (70\% ML bootstrap value). $\mathrm{CR} 11^{\mathrm{T}}$ is most closely related to the environmental clone RIN3BA4 obtained from the same hot spring (Fig. 2). The closest described isolate to $\mathrm{CR} 11^{\mathrm{T}}$ is $T$. ruber OC $1 / 4^{\mathrm{T}}$ (95.7\% similar in $16 \mathrm{~S}$ rRNA gene sequence). Strain $\mathrm{CR} 11^{\mathrm{T}}$ and clone RIN3BA4 form a lineage separate from $T$. ruber OC $1 / 4^{\mathrm{T}}$ and related strains. Together, these two lineages form a clade with Hydrogenobacter $(80 \% \mathrm{ML}$ bootstrap value), while the $T$. albus-like group forms a separate monophyletic lineage (Fig. 2). Strain $C R 11^{\mathrm{T}}$ is $>95 \%$ similar in the $16 \mathrm{~S}$ rRNA gene to most sequences of the T. ruber-like clade. For example, CR $11^{\mathrm{T}}$ is $95.1 \%$ similar to the clone sequence EM17 (Reysenbach et al., 1994) and $95.2 \%$ similar to Thermocrinis sp. P2L2B (Eder \& Huber, 2002). The new isolate and clone RIN3BA4 are less than $95 \%$ similar in the $16 \mathrm{~S}$ rRNA gene (below the cut-off for relatedness at the genus level; Stackebrandt \& Goebel, 1994) to all sequences within the T. albus-like clade ( $94.8 \%$ similarity between $\mathrm{CR} 11^{\mathrm{T}}$ and T. albus $\mathrm{HI} 11 / 12^{\mathrm{T}}$ ).

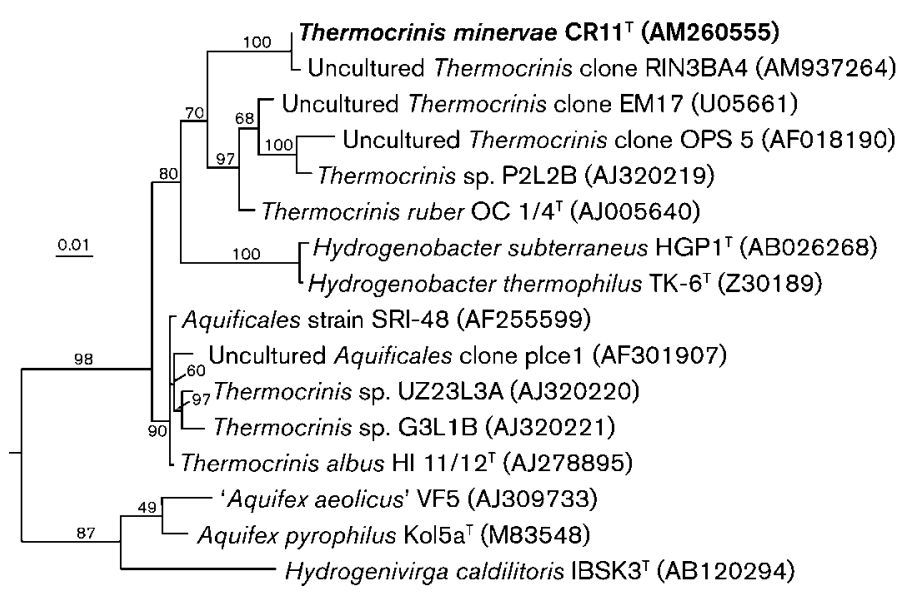

Fig. 2. Maximum-likelihood phylogenetic tree inferred from 16S rRNA gene sequences $(1370 \mathrm{nt})$ showing the relative position of strain $\mathrm{CR} 11^{\top}$ within the Aquificaceae. Bootstrap values correspond to 100 replicates. The tree topology was confirmed by the neighbour-joining algorithm. Bar, 0.01 substitutions per nucleotide position. 
The phylogenetic distance between these groups is similar to the previously reported distance of $5.1 \%$, based on maximum-parsimony analysis, between $T$. ruber OC $1 / 4^{\mathrm{T}}$ and T. albus $\mathrm{HI} 11 / 12^{\mathrm{T}}$ (Eder \& Huber, 2002).

The strains of Thermocrinis (including $\mathrm{CR} 11^{\mathrm{T}}$ ) are physiologically similar with respect to growth temperature range, low $\mathrm{NaCl}$ tolerance and electron donor/acceptor pairs used for chemolithotrophic growth (Table 1). However, they differ significantly in their ability to use organic carbon sources. Among these strains, CR $11^{\mathrm{T}}$ appears to be metabolically more similar to $T$. ruber than to T. albus, in that $\mathrm{CR} 11^{\mathrm{T}}$ is also capable of growing on organic carbon sources. However, $\mathrm{CR} 11^{\mathrm{T}}$ grows on a greater diversity of organic carbon sources than T. ruber (Table 1). Furthermore, $\mathrm{CR} 11^{\mathrm{T}}$ has a lower $\mathrm{G}+\mathrm{C}$ content than either $T$. ruber or $T$. albus. Therefore, based on physiological and phylogenetic characteristics, we propose the novel species Thermocrinis minervae sp. nov. to accommodate strain $\mathrm{CR} 11^{\mathrm{T}}$.

\section{Description of Thermocrinis minervae sp. nov.}

Thermocrinis minervae (mi.ner'vae. L. fem. gen. n. minervae from Minerva, a Roman goddess, also known as Pallas Athena in Greek mythology, considered to be the virgin goddess of science, medicine and wisdom).

Motile, Gram-negative rods, approx. 2.4-3.9 $\mu \mathrm{m}$ long and $0.5-0.6 \mu \mathrm{m}$ wide. Cells occur singly. Growth occurs at $65-$ $85{ }^{\circ} \mathrm{C}$ (optimum $75{ }^{\circ} \mathrm{C}$ ), $\mathrm{pH} 4.8-7.8$ (optimum $\mathrm{pH} 5.9$ $6.5)$ and $0-0.4 \%(\mathrm{w} / \mathrm{v}) \mathrm{NaCl}$. Grows chemolithoautotrophically with $\mathrm{H}_{2}, \mathrm{~S}^{0}$ and $\mathrm{S}_{2} \mathrm{O}_{3}^{2-}$ as electron donors and with only $\mathrm{O}_{2}$ (up to $16 \%, \mathrm{v} / \mathrm{v}$ ) as the electron acceptor. Able to use yeast extract, mannose, glucose, maltose, succinate, peptone, Casamino acids, starch, citrate and $\mathrm{CO}_{2}$ as carbon sources. The $\mathrm{G}+\mathrm{C}$ content of genomic DNA of the type strain is $40.3 \mathrm{~mol} \%$.

The type strain, CR $11^{\mathrm{T}}\left(=\mathrm{DSM} 19557^{\mathrm{T}}=\right.$ ATCC BAA$\left.1533^{\mathrm{T}}\right)$, was isolated from a terrestrial hot spring on the south-western foothills of the Rincón de la Vieja volcano in Costa Rica.

\section{Acknowledgements}

The authors thank Ana Sittenfeld for her assistance in sample collection. This work was supported by the grants NSF-PEET DEB0328326 and NSF-MCB-0084224 awarded to A.-L.R. S. L.C. was supported by the OSU-PSU IGERT program, NSF-0114427. Electron microscopy was performed in the NSERC Guelph Regional Integrated Imaging Facility (GRIIF), which was partially funded by a NSERC Major Facility Access grant to T. J. B. The authors also wish to thank Dianne Moyles, University of Guelph, for her assistance with the electron microscopy.

\section{References}

Aguiar, P., Beveridge, T. J. \& Reysenbach, A. L. (2004). Sulfurihydrogenibium azorense sp. nov., a thermophilic hydrogen- oxidizing microaerophile from terrestrial hot springs in the Azores. Int J Syst Evol Microbiol 54, 33-39.

Barion, S., Franchi, M., Gallori, E. \& Di Giulio, M. (2007). The first lines of divergence in the Bacteria domain were the hyperthermophilic organisms, the Thermotogales and the Aquificales, and not the mesophilic Planctomycetales. Biosystems 87, 13-19.

Beveridge, T. J., Popkin, T. J. \& Cole, R. C. (1994). Electron microscopy. In Methods for General and Molecular Bacteriology, pp. 42-71. Edited by P. Gerhardt. Washington, DC: American Society for Microbiology.

Blank, C. E., Cady, S. L. \& Pace, N. R. (2002). Microbial composition of near-boiling silica-depositing thermal springs throughout Yellowstone National Park. Appl Environ Microbiol 68, 5123-5135.

Burggraf, S., Olsen, G. J., Stetter, K. O. \& Woese, C. R. (1992). A phylogenetic analysis of Aquifex pyrophilus. Syst Appl Microbiol 15, 352-356.

Connon, S. A., Koski, A. K., Neal, A. L., Wood, S. A. \& Magnuson, T. S. (2008). Ecophysiology and geochemistry of microbial arsenic oxidation within a high arsenic, circumneutral hot spring system of the Alvord Desert. FEMS Microbiol Ecol 64, 117-128.

Di Giulio, M. (2003a). The universal ancestor was a thermophile or a hyperthermophile: tests and further evidence. J Theor Biol 221, 425436.

Di Giulio, M. (2003b). The ancestor of the Bacteria domain was a hyperthermophile. J Theor Biol 224, 277-283.

Di Giulio, M. (2003c). The universal ancestor and the ancestor of the Bacteria were hyperthermophiles. J Mol Evol 57, 721-730.

Eder, W. \& Huber, R. (2002). New isolates and physiological properties of the Aquificales and description of Thermocrinis albus sp. nov. Extremophiles 6, 309-318.

Ferrera, I., Longhorn, S., Banta, A. B., Liu, Y., Preston, D. \& Reysenbach, A. L. (2007). Diversity of $16 \mathrm{~S}$ rRNA gene, ITS region and aclB gene of the Aquificales. Extremophiles 11, 57-64.

Flores, G. E., Liu, Y., Ferrera, I., Beveridge, T. J. \& Reysenbach, A.-L. (2008). Sulfurihydrogenibium kristjanssonii sp. nov., a hydrogen- and sulfur-oxidizing thermophile isolated from a terrestrial Icelandic hot spring. Int J Syst Evol Microbiol 58, 1153-1158.

Götz, D., Banta, A., Beveridge, T. J., Rushdi, A. I., Simoneit, B. R. T. \& Reysenbach, A.-L. (2002). Persephonella marina gen. nov., sp. nov. and Persephonella guaymasensis sp. nov., two novel, thermophilic, hydrogen-oxidizing microaerophiles from deep-sea hydrothermal vents. Int J Syst Evol Microbiol 52, 1349-1359.

Hall, J. R., Mitchell, K. R., Jackson-Weaver, O., Kooser, A. S., Cron, B. R., Crossey, L. J. \& Takacs-Vesbach, C. D. (2008). Molecular characterization of the diversity and distribution of a thermal spring microbial community by using rRNA and metabolic genes. Appl Environ Microbiol 74, 4910-4922.

Huber, R., Wilharm, T., Huber, D., Trincone, A., Burggraf, S., König, H., Rachel, R., Rockinger, I., Fricke, H. \& Stetter, K. O. (1992). Aquifex pyrophilus gen. nov., sp. nov., represents a novel group of marine hyperthermophilic hydrogen-oxidizing bacteria. Syst Appl Microbiol 15, 340-351.

Huber, R., Eder, W., Heldwein, S., Wanner, G., Huber, H., Rachel, R. \& Stetter, K. O. (1998). Thermocrinis ruber gen. nov., sp. nov., a pinkfilament-forming hyperthermophilic bacterium isolated from Yellowstone National Park. Appl Environ Microbiol 64, 3576-3583.

Jahnke, L. L., Eder, W., Huber, R., Hope, J. M., Hinrichs, K. U., Hayes, J. M., Des Marais, D. J., Cady, S. L. \& Summons, R. E. (2001). Signature lipids and stable carbon isotope analyses of Octopus Spring hyperthermophilic communities compared with those of Aquificales representatives. Appl Environ Microbiol 67, 5179-5189. 
Kawasumi, T., Igarashi, Y., Kodama, T. \& Minoda, Y. (1984). Hydrogenobacter thermophilus gen. nov., sp. nov., an extremely thermophilic, aerobic, hydrogen-oxidizing bacterium. Int $J$ Syst Bacteriol 34, 5-10.

Kristjansson, J. K., Ingason, A. \& Alfredsson, G. A. (1985). Isolation of thermophilic obligately autotrophic hydrogen-oxidizing bacteria, similar to Hydrogenobacter thermophilus, from Icelandic hot springs. Arch Microbiol 140, 321-325.

Kryukov, V. R., Savelyeva, N. D. \& Pusheva, M. A. (1983). Calderobacterium hydrogenophilum nov. gen., nov. sp., an extremely thermophilic hydrogen bacterium, and its hydrogenase activity. Mikrobiologiia 52, 781-788 (in Russian).

Ludwig, W., Strunk, O., Westram, R., Richter, L., Meier, H., Yadhukumar, Buchner, A., Lai, T., Steppi, S. \& other authors (2004). ARB: a software environment for sequence data. Nucleic Acids Res 32, 1363-1371.

Marmur, J. \& Doty, P. (1962). Determination of the base composition of deoxyribonucleic acid from its thermal denaturation temperature. J Mol Biol 5, 109-118.

Nakagawa, S., Shtaih, Z., Banta, A., Beveridge, T. J., Sako, Y. \& Reysenbach, A.-L. (2005). Sulfurihydrogenibium yellowstonense sp. nov., an extremely thermophilic, facultatively heterotrophic, sulfuroxidizing bacterium from Yellowstone National Park, and emended descriptions of the genus Sulfurihydrogenibium, Sulfurihydrogenibium subterraneum and Sulfurihydrogenibium azorense. Int J Syst Evol Microbiol 55, 2263-2268.

Nishihara, H., Igarashi, Y. \& Kodama, T. (1990). A new isolate of Hydrogenobacter, an obligately chemolithotrophic, thermophilic, halophilic and aerobic hydrogen-oxidizing bacterium from seaside saline hot spring. Arch Microbiol 153, 294-298.

Pitulle, C., Yang, Y., Marchiani, M., Moore, E. R. B., Siefert, J. L., Aragno, M., Jurtshuk, P., Jr \& Fox, G. E. (1994). Phylogenetic position of the genus Hydrogenobacter. Int J Syst Bacteriol 44, 620-626.

Reysenbach, A. L., Whickham, G. S. \& Pace, N. R. (1994). Phylogenetic analysis of the hyperthermophilic pink filament community in Octopus Spring, Yellowstone National Park. Appl Environ Microbiol 60, 2113-2119.

Shima, S. \& Suzuki, K. (1993). Hydrogenobacter acidophilus sp. nov., a thermoacidophilic, aerobic, hydrogen-oxidizing bacterium requiring elemental sulfur for growth. Int J Syst Bacteriol 43, 703-708.

Stackebrandt, E. \& Goebel, B. M. (1994). Taxonomic note: a place for DNA-DNA reassociation and $16 \mathrm{~S}$ rRNA sequence analysis in the present species definition in bacteriology. Int J Syst Bacteriol 44, 846849.

Swofford, D. L. (2003). PAUP* Phylogenetic analysis using parsimony (and other methods). Sunderland, MA: Sinauer Associates. 